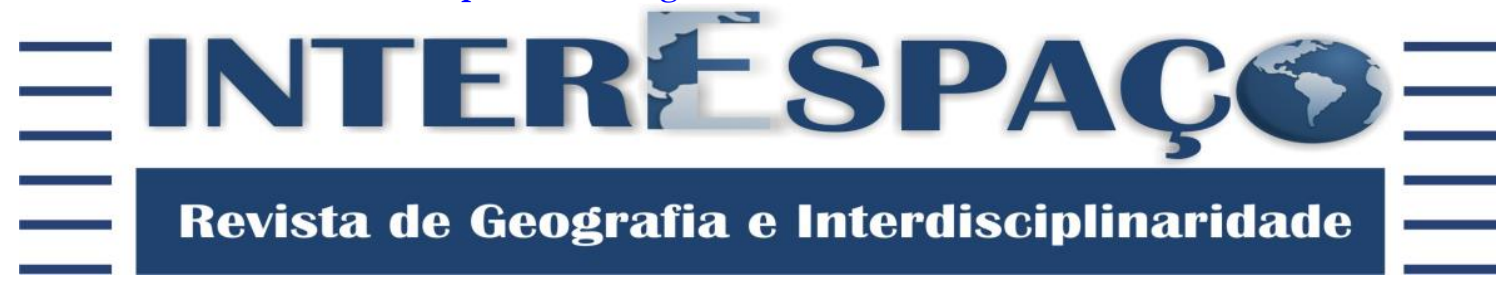

\title{
CANTO DA MATA: um convite geopoético aos nossos parques
} nacionais

SONG OF THE FOREST: a geopoetic invitation to our national parks

CANTO DEL BOSQUE: una invitación geopoética a nuestros parques nacionales

\section{Francisco Fernando Livino de Carvalho}

Mestre em Ecoturismo e Conservação pela Universidade Federal do Estado do Rio de Janeiro PPGEC/UNIRIO.

francisco.livino@icmbio.gov.br / http://orcid.org/0000-0003-1154-8525

\section{Luiza Corral Martins de Oliveira Ponciano}

Doutora e Mestra em Geologia pela Universidade Federal do Rio de Janeiro - UFRJ. Docente do Departamento de Ciências Naturais e do Mestrado Profissional em Ecoturismo e Conservação da Universidade Federal do Estado do Rio de Janeiro - PPGEC/UNIRIO. luiza.ponciano@unirio.br / http://orcid.org/0000-0001-6700-2391

Recebido: 26/02/2020; Aceito: 14/01/2021; Publicado: 19/08/2021.

\section{RESUMO}

O projeto Canto da Mata se propõe a seduzir, informar e convidar a sociedade, por meio do encantamento poético, a se apropriar de suas áreas protegidas. Este artigo apresenta algumas composições, focando especialmente no Parque Nacional da Serra da Bocaina (RJ-SP). A fim de ampliar o alcance da mensagem conservacionista para além das fronteiras das unidades de conservação, busca-se retratar e comunicar a Natureza como faziam os grandes viajantes naturalistas do século XIX, tais como Humboldt, Langsdorff, Spix e Martius, dentre tantos outros, aliando investigação e deslumbramento. Por meio de uma abordagem Geopoética, a valorização de um "pensar-sentindo" pode atenuar as fronteiras entre Arte e Ciência e oferecer caminhos para a necessária e urgente reconciliação da sociedade contemporânea com a Natureza.

Palavras-chave: Interpretação Ambiental; Ecoturismo; Geopoética; Parque Nacional da Serra da Bocaina.

\section{ABSTRACT}

The Canto da Mata project aims to seduce, inform and invite society, through poetic enchantment, to appropriate its protected areas. This article presents some compositions, focusing especially on the Serra da Bocaina National Park (RJ-SP). In order to extend the scope of the conservationist message beyond the borders of conservation units, we seek to portray and communicate Nature as the great naturalistic travelers of the 19th century did, such as Humboldt, Langsdorff, Spix and Martius, among many others, combining investigation and wonder. Through a Geopoetic approach, the valorization of a "thinking-feeling" can soften the boundaries between Art and Science and offer paths for the necessary and urgent reconciliation of contemporary society with Nature.

Keywords: Environmental Interpretation; Ecotourism; Geopoetics; Serra da Bocaina National Park.

\section{RESUMEN}


|Francisco Fernando Livino de Carvalho | Luiza Corral Martins de Oliveira Ponciano|

El proyecto Canto da Mata tiene como objetivo seducir, informar e invitar a la sociedad, a través del encanto poético, a apropiarse de sus áreas protegidas. Este artículo presenta algunas composiciones, centrándose especialmente en el Parque Nacional Serra da Bocaina (RJ-SP). Con el fin de extender el alcance del mensaje conservacionista más allá de las fronteras de las unidades de conservación, buscamos retratar y comunicar la Naturaleza como lo hicieron los grandes viajeros naturalistas del siglo XIX, como Humboldt, Langsdorff, Spix y Martius, entre muchos otros. combinando investigación y asombro. A través de un enfoque Geopoético, la valorización de un "pensamiento-sentimiento" puede suavizar los límites entre Arte y Ciencia y ofrecer caminos para la necesaria y urgente reconciliación de la sociedad contemporánea con la Naturaleza.

Palabras clave: Interpretación Ambiental; Ecoturismo; Geopoética; Parque Nacional Serra da Bocaina.

\section{INTRODUÇÃO: nossos parques, nossa música - o cenário}

O Brasil é um país que apresenta notório destaque por seus atributos naturais, sendo o campeão do ranking de competitividade turística em relação a esse aspecto (W.E.F., 2017), além de disputar o "título" de país mais rico em diversidade biológica do planeta (MITTERMEIER et al., 2005). Esta enorme riqueza, entretanto, ainda tem pouca inserção no dia a dia dos brasileiros. Os números de visitação dos nossos parques nacionais, por exemplo, ainda ficam bem abaixo do potencial que apresentam, apesar do crescimento regular nos últimos anos. Exemplificando: enquanto no ano de 2018 foram registrados 12,4 milhões de visitantes nas unidades de conservação (UC) federais do país, considerando todas as categorias (ICMBio, 2020), somente os parques nacionais dos Estados Unidos registraram, no mesmo ano, mais de 84 milhões de visitantes (NPS, 2019). Considerando a disparidade econômica entre os países, no entanto, buscamos parâmetro em um país vizinho e de economia similar à brasileira: No ano de 2019 foram registrados 3,5 milhões de visitantes nos parques nacionais do Chile (CONAF, 2020); enquanto no Brasil foram 15 milhões (ICMBIO, 2020). Apesar dos números absolutos maiores, quando comparados ao tamanho das populações dos países, encontramos uma grande disparidade em números proporcionais. Caso apresentássemos uma proporção semelhante à do Chile, de visitantes por população do país, teríamos registrado cerca de 36 milhões de visitantes em nossos parques, mais do que o dobro do atual. Embora diversas variáveis tenham influência sobre essa atratividade, esses números ilustram a necessidade de ampliar a conexão da população brasileira com as suas áreas protegidas, justificando a proposição de ações nesse sentido.

Considerando, ainda, que no Brasil cerca de $85 \%$ da população vive em áreas urbanas, chegando a 93\% na região Sudeste (IBGE, 2019), pode-se estimar um real distanciamento geográfico da nossa sociedade com quaisquer áreas naturais, uma vez que 
|Francisco Fernando Livino de Carvalho | Luiza Corral Martins de Oliveira Ponciano|

mora apartada e não as visita, como visto acima. Acredita-se que esse afastamento é um dos fatores responsáveis pela notória fragilidade das pautas ambientais ante a "arena política” do país (FREY, 2000), evidenciada pela estrutura extremamente deficitária disponível para a gestão dos parques e demais reservas nacionais (BRAGA; MACIEL; 2011), ou, por exemplo, pela pouquíssima reação social aos recentes processos de desafetação de unidades de conservação em detrimento de projetos energéticos no norte do país (SILVA JUNIOR; SANTOS; SZLAFSZTEIN, 2015).

Em vista desse cenário há hoje um intenso esforço institucional do governo federal, por meio do ICMBio (Instituto Chico Mendes de Conservação da Biodiversidade), assim como de pesquisadores e demais atores sociais relacionados, pelo incremento do ecoturismo nas UC, acreditando no impacto positivo dessa atividade, sob a lógica do repetido "mantra" - "conhecer para [se encantar e] ${ }^{1}$ conservar" - buscando corrigir uma rota gerencial pública no país que, há até uma década, ainda era sensivelmente refratária à visitação (ZIMMERMANN, 2006). A curva ascendente de visitação nos parques brasileiros é uma consequência deste esforço, sendo, inclusive, resultado de uma maior ênfase no registro dessas visitas. Algo que se percebe, entretanto, é o que costumamos chamar de "pregar para convertido", uma vez que, normalmente, o que se vê em fóruns e eventos relacionados às UC e ao ecoturismo é a presença de um público já afeto ao tema, com pouca renovação. Em face dessa percepção é que acreditamos ser necessário diversificar as estratégias de comunicação, buscando atingir outras pessoas, de outras formas.

Assim como a nossa biodiversidade, a música popular brasileira tem relevância inegável. Tanto no que se refere ao seu protagonismo como tradutora e intérprete das múltiplas identidades culturais brasileiras (ICCA, 2019), quanto em relação ao seu valor como "produto de exportação" de reconhecida qualidade, gozando de presença marcante no cotidiano da população (SALDANHA, 2013). Em vista disso, apostamos na música e na poesia como expressões de linguagem lúdica, ainda pouco utilizadas, para a comunicação do ecoturismo e da conservação ambiental uma linguagem promissora para o incremento do alcance dessa mensagem, podendo contribuir com a visitação nos parques nacionais.

\section{METODOLOGIA: uma imersão Geopoética}

A elaboração de produtos interpretativos, no caso específico poemas e canções, deve seguir alguns passos que julgamos fundamentais: I - Imersão Geopoética (colher as

\footnotetext{
${ }^{1}$ Inserção dos autores.
} 
|Francisco Fernando Livino de Carvalho | Luiza Corral Martins de Oliveira Ponciano|

sementes): o primeiro passo fundamental que se coloca é o de buscar se aproximar o mais possível do espírito do lugar a ser retratado, o seu Genius-loci (NORBERG-SCHULZ, 2006). Defende-se que isto só se pode dar por meio de uma imersão nos estímulos naturais oriundos do habitat (e de seus habitantes), fenômenos qualitativos que, além da razão, requerem a estimulação do sensível, de modo a se poder "captar as conexões, as relações, a estrutura da realidade geográfica" (CANTERO, 2010); II - Amplificação artística (regar a terra): uma vez apreendidos os desejos e expressões do ambiente, faz-se necessário ao intérprete traduzi-los para "linguagens inteligíveis" aos homens, como descreve Tuan (2013). Assim como na academia se recorre ao referencial teórico, para a produção artística há também importantes referenciais. É nas obras já produzidas que encontraremos os caminhos que nos auxiliarão a chegar em nossa própria linguagem. É vastíssimo o cancioneiro popular brasileiro que reflete nossa natureza, assim como o é a iconografia, a culinária, a arquitetura etc. Quanto mais em contato com estes, mais vasto tenderá a ser o vocabulário para traduzir aquelas mensagens que colhemos na natureza; III - Da análise à síntese (podar a planta): se a natureza é o motivo e a recompensa, traduzir a sua grandiosidade em uma obra de arte, por mais abrangente que ela ouse ser, será sempre um exercício de síntese. Não há como fazer caber, cada um dos tesouros colhidos em campo, cada som, cada cheiro, cada imagem grandiosa... em algo que, necessariamente, pressupõe limites (uma tela, uma página, os minutos de uma canção...). Faz-se necessário, então, procurar dentro de todo o escopo de estímulos colhidos (arte e natureza), aquilo que se mostra essencial, aquilo que pulsa e se faz notar como mais expressivo, a frutificar no último passo; IV. Linguagem Geopoética (nascem os frutos): por meio dos passos dados chegamos aos produtos que vão estruturando o Canto da Mata. Espera-se que, por meio desses frutos, se possa seduzir a sociedade, trazendo-a para um convívio mais íntimo e mais afetivo com seus patrimônios naturais, uma vez que "só a imagem poética, em suas virtudes ontológicas, possui a capacidade de recompor a completude da existência" (CRAPEZ, 2015).

\section{INTERPRETANDO ECOTURISMO E CONSERVAÇÃO}

A música, assim como os livros, a iconografia, os documentários audiovisuais etc. podem ser importantes "convites" para a realização do ecoturismo, ao traduzirem uma Natureza que é capaz de encantar, mesmo a distância. Este encantamento, contudo, tende a ser muito mais eloquente quando vivenciado in loco. Com base na máxima "uma imagem vale mais que mil palavras", poderia se dizer que uma vivência em uma UC vale mais que 
|Francisco Fernando Livino de Carvalho | Luiza Corral Martins de Oliveira Ponciano|

mil imagens. O estímulo reflexivo produzido pelas práticas interpretativas e educativas unese aos estímulos sensoriais do meio ambiente (imagens, sons, temperaturas, aromas...), promovendo experiências que unem teoria e prática. Autores como Hanai e Netto (2006), no entanto, destacam o quanto o ser humano "civilizado" reduziu a sua capacidade de interação com os ambientes "selvagens". Do mesmo modo que se requer a existência de trilhas, pontes, escadas e outras estruturas que ofereçam uma maior sensação de segurança e conforto no deslocamento físico, estímulos cognitivos podem ser fundamentais para uma incursão subjetiva estimulante e, possivelmente, transformadora. Torna-se, portanto, uma responsabilidade inerente ao planejamento ecoturístico promover a facilitação e o estímulo adequado para que a visita a uma área natural vá muito além de um mero "consumo" da paisagem (MENDONÇA; NEYMAN, 2000).

O próprio conceito de paisagem, como visto pela geografia moderna, requer essa apreensão ao mesmo tempo entre a razão e o sentimento, sendo um conceito oriundo de maneira híbrida da arte e da ciência, nascido do romantismo e dos naturalistas do século XIX (CANTERO, 2010). Ou, como descrito na Carta da Paisagem das Américas (IFLA AMÉRICA, 2018, p. 10): "continuum de sistemas vivos, naturales y culturales, como una totalidad sintética e interdependiente, en el espacio y en el tempo".

A visitação de parques nacionais e outras áreas protegidas, portanto, pode estimular (re)conhecimentos e afetos pela Natureza e o auxílio a esses estímulos é o que cabe à Interpretação Ambiental: "ferramenta de manejo" de áreas protegidas que surgiu como disciplina exatamente para a gestão e proteção de terras públicas”, seja de forma pessoal (guias), seja por meio de recursos indiretos, tais como: mídias e estruturas físicas, como painéis, por exemplo (ICMBio, 2018). Como se trata de um processo de construção de laços afetivos a resposta será sempre individual, relacional e, portanto, fenomenológica, demandando uma participação ativa e criadora na relação entre intérprete e público (CRAPEZ, 2015). Assim sendo, se não puderem ser criados vínculos entre a mensagem e o universo pessoal do interlocutor, este não será capaz de construir sentidos para a informação recebida (ICMBio, 2018). Ao contrário, se a interpretação atinge o seu objetivo, tende-se a se construir aprendizados, levando o visitante a adjetivar o "espaço", transformando-o em "lugar", dando-lhe personalidade e um sentido particular (TUAN, 2013; HANAI e NETO, 2006). Assim, o intérprete, em sua poética, torna-se um "estrategista" do tema interpretado, parafraseando White (1994) e conduzindo à abordagem Geopoética que estrutura o presente artigo (PONCIANO, 2018).

\section{UMA RECONCILIAÇÃO GEOPOÉTICA}


|Francisco Fernando Livino de Carvalho | Luiza Corral Martins de Oliveira Ponciano|

Longe das cidades, os povos tradicionais têm na Natureza sua vida e sua essência. Topografia, clima, animais e vegetais são seus ciclos, sua morada e seus desafios reais cotidianos. São ainda seus mitos e divindades e sua poesia (CRAPEZ, 2015). Em contrapartida, nas grandes áreas urbanas (como visto na introdução) vive-se alheio aos ambientes naturais, construindo-se laços cada vez mais frágeis com o nosso berço natural (TUAN, 2013).

São diversas as "lentes" pelas quais podemos ler a natureza (CARVALHO, 2004): Ela pode ser encarada meramente como fonte primária de recursos, como o é sob a lente hegemônica do capitalismo, e desse modo o cerne do discurso conservacionista se baseia na simples continuidade do provimento de recursos. Existem, no entanto, diversas outras "lentes" (éticas, estéticas, religiosas...) que louvam a natureza por sua própria existência, seu valor intrínseco, imanente, independentemente de seu uso direto. Ainda pelo que poderíamos chamar de uma "lente geológica", a conservação da natureza pode ser encarada como uma necessidade muito mais humana do que dela própria. Na campanha “\#ANaturezaEstaFalando”, da ONG Conservação Internacional, tal viés é explorado de forma incisiva, quando "a voz da Mãe Natureza” dá o alerta: "Eu estou aqui há mais de quatro bilhões e meio de anos, na verdade eu não preciso de vocês. As pessoas precisam de mim...”. Tal campanha já foi vista por mais de oito milhões de pessoas em todo mundo, considerando o vídeo em língua inglesa ${ }^{2}$. Infelizmente as versões em língua portuguesa ${ }^{3}$ e espanhola ${ }^{4}$ alcançam números significativamente menores de visualizações.

As artes modernas abraçaram a ideia de um novo mundo, para o qual a natureza e a história não mais serviam como referência. A arte abstrata, o cubismo, o futurismo, o construtivismo, dentre outros movimentos surgidos na primeira metade do século passado eram a materialização artística da sociedade das máquinas e do progresso (CRAPEZ, 2017). Uma maquinização da vida que acabou por desenraizar o homem de seu próprio cosmo natural (MENÉNDEZ, 2018).

Como consequência dessas heranças da ciência cartesiana, vive-se hoje um desencantamento perante o mundo. O homem contemporâneo, herdeiro do modernismo, cria aparatos mentais e materiais para a compreensão da natureza que mais a escondem do que a revelam. Torna-se capaz de compreender detalhes cada vez mais isolados, mas se torna cego e surdo para a vastidão (DANIEL, 2009). Essa desconexão sensível e geográfica entre as pessoas e os estímulos dos ambientes naturais já se configura como a causa de problemas de saúde (autismo, depressão, ansiedade...), cada vez mais presentes nas

\footnotetext{
${ }^{2}$ https: / www.youtube.com/watch?time continue $=5 \& v=W m V L c j-X K n M$

${ }^{3}$ https://www.youtube.com/watch?v=Uq6brcVVh6Y

${ }^{4}$ https://www.youtube.com/watch?v=wTkMFSgqi1I
} 
|Francisco Fernando Livino de Carvalho | Luiza Corral Martins de Oliveira Ponciano|

sociedades urbanas (CALVO-MUÑOZ, 2014; LOUV, 2016). No campo das artes e da cultura vive-se hoje uma crise estética e subjetiva decorrente de uma massificação cultural globalizada, que molda as preferências populares por meio de fórmulas padronizadas, repetitivas e alheias às referências culturais das comunidades. Arte e cultura são, desse modo, transformadas em objetos de consumo como outros quaisquer, e seu público, consequentemente, torna-se um mero consumidor, alienado do bem cultural e da própria vida (OLIVEIRA, 2008).

$\mathrm{Na}$ contramão da cultura hegemônica e globalizante do positivismo, entretanto, diversas iniciativas buscam o (re)encantamento com o mundo desde o romantismo, que surgiu no século XIX glorificando as paisagens naturais principalmente pela poesia e pela pintura, querendo reencontrar na natureza "espelhos da alma, mediação entre o ser humano e o cosmos" (CRAPEZ, 2015). Essa reconciliação, mais que uma necessidade, é um desejo estético, um desejo de algo novo, mas um novo que se forja na ancestralidade. Segundo Fortes Jr. (2009), caberia exatamente ao artista repor ao ser humano este contato mais sensível com a natureza. De certa forma devolver-lhe o sentido de sagrado, como buscavam os românticos. Segundo White (1994), entretanto, o poeta, nesse aspecto, não pode mais se ater à mera sentimentalidade, pois carrega a responsabilidade de um tema, de uma investigação. Não lhe basta mais apenas se exprimir, mas sim, agir como "um estrategista". Deve-se buscar o resgate da "inteireza" do mundo, por meio de uma linguagem da Natureza que não se apreende só pela razão, à qual o autor denomina Geopoética (WHITE, 1994).

A partir da fonte cunhada por White diversos autores exploram na paisagem variados sentidos, indo muito além da visão, tão associada ao termo. Kozel (2012), por exemplo, estabelece na tríade - olhar, sentir e ouvir - um caminho para desvendar a alma do lugar, o mesmo Genius loci concebido por Norberg-Schulz. Ao trazer para a discussão os aspectos relacionados à paisagem sonora, Kozel (2012) explora a Geopoética em um aspecto menos convencional a compor a paisagem: os sons da Natureza (incluindo, é claro, aqueles vindos dos seres humanos). Adentramos assim o território do Canto da Mata, que busca sonoridades que concedam às paisagens familiaridade e expressão (TORRES; KOZEL, 2010). Antes, porém, de adentrar no Canto da Mata, é interessante começar pelo relato de uma vivência pessoal, particularmente significativa no contexto de criação deste trabalho.

\section{ELOMAR E A CAATINGA, UMA PONTE GEOPOÉTICA}


|Francisco Fernando Livino de Carvalho | Luiza Corral Martins de Oliveira Ponciano|

Era a primeira semana de dezembro de 2013, durante uma viagem ao Parque Nacional da Serra da Capivara, no sertão do Piauí. Após o primeiro dia de incursões pelo parque, tivemos o privilégio e a sorte de presenciar a chegada da primeira grande chuva do ano, ressuscitadora da vida naquele bioma (Figura 1). Pouco antes, ainda à tarde, nosso guia, havia chamado nossa atenção para grandes árvores da caatinga (mestras na arte de ensinar ao sertanejo a resiliência ante os rigores climáticos da região), mortas por uma seca excepcional de três anos que se encerraria, finalmente, poucas horas mais tarde. Naquele momento, ao testemunhar a tormenta que lavava o boqueirão e refrescava a alma, para a festa de dois enormes gaviões que voavam abaixo, a minha razão foi excepcionalmente gentil e cedeu passagem à mais pura emoção. Lágrimas e chuva prepararam os sertões de "minh'alma" para os campos em "fulô" 5 que transformariam a caatinga para seus meses de fartura. Graças ao estudo da Geopoética, ao longo do mestrado em Ecoturismo e Conservação (PPGEC-UNIRIO), tal conexão aflorou, seis anos depois, no campo da "consciência". Pelo pensamento reflexivo da racionalidade as emoções fugidas do passado foram resgatadas e ganharam permanência (TUAN, 2013).

Resgatamos, então, o motivo da emoção que propiciou tal conexão sensitiva: desde muito cedo, fui apresentado à obra de Elomar Figueira Melo, compositor baiano de Vitória da Conquista, inaugurando uma paixão definitiva que me acompanha até hoje. A obra de Elomar se vale de uma linguagem dialetal "sertaneza", para compor sua poética, e de um instrumental que remete às origens medievais portuguesas, até pouco tempo ainda ricamente preservadas no interior nordestino, para retratar a alma do lugar, a "paisagem vivida" da caatinga do sertão baiano por meio da cognição, percepção, afetividade, memória, alienação e construção de imagens (GUIMARÃES, 2002).

Constatamos hoje, portanto, por meio do "pensar-sentindo" da Geopoética, que foi a arte de Elomar que construiu a ponte entre a natureza e a minha subjetividade, que transbordou naquela primeira grande chuva lá num boqueirão da Serra da Capivara.

Tal constatação confirma, por meio de um exemplo concreto e pessoal, o pressuposto que é alicerce para a concepção do Canto da Mata: o de que a arte é um importante caminho para (re)criar conexões afetivas do ser humano com a natureza, caminho para promover a tão necessária reconciliação de nossa sociedade com a Terra.

\footnotetext{
5 "flor", em dialeto sertanejo.

${ }^{6}$ Conforme fala do próprio Elomar.
} 


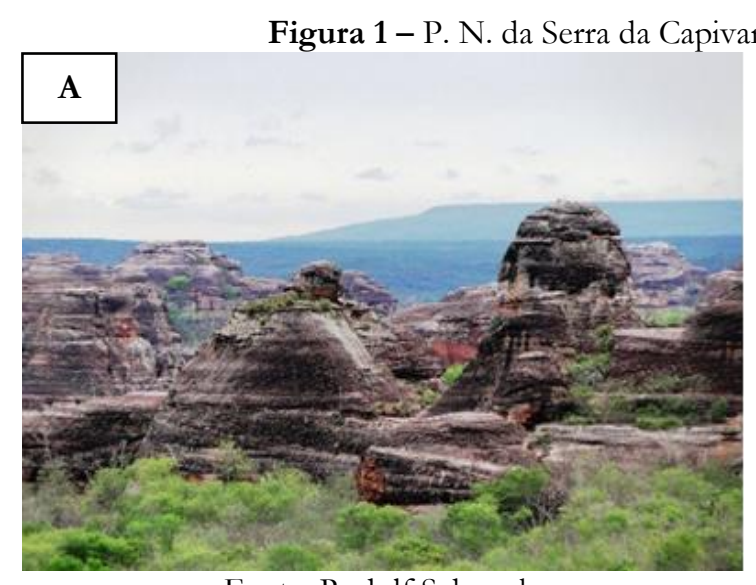

Fonte: Rudolf Schwark.

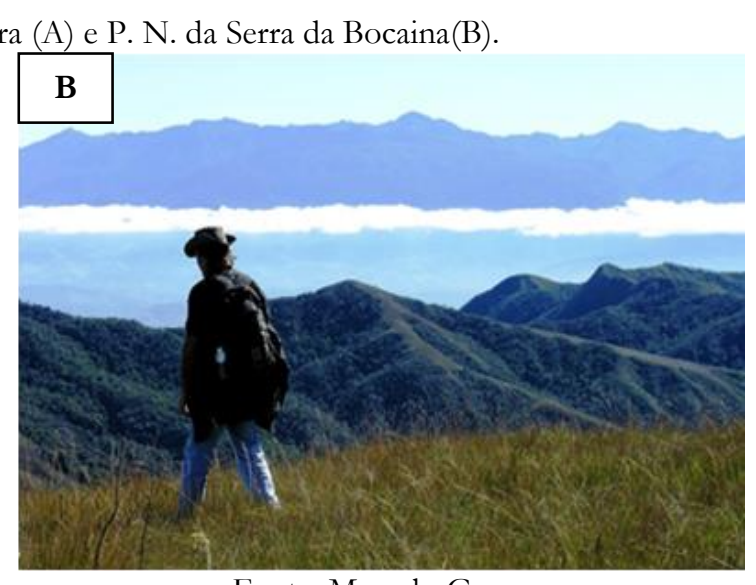

Fonte: Marcelo Guena.

\section{O CANTO DA MATA}

A música, que assume importante papel na cultura de um povo, compõe também a paisagem. Os valores dos grupos são retratados nas canções, assim como suas relações com o meio em que habitam (KOZEL, 2012). Retratar uma paisagem, entretanto, não é simplesmente copiar seus aspectos físicos. Ela passa sempre pelo desejo de expor a própria alma do artista (intérprete) na concepção, auxiliando a construir a "cosmovisão" a que se refere a Carta de Paisage de Las Americas (IFLA AMÉRICA, 2018).

Antigos pintores chineses, por exemplo, em vez de irem para o campo com suas tintas e cavaletes, preferiam vaguear por horas, ou mesmo por dias, para absorver a atmosfera do ambiente. De volta ao atelier, então, filtrada pela subjetividade, a paisagem era assim retratada (TUAN, 2012).

Interpretar o mundo pela Geopoética, de acordo com White (1990), propõe o resgate da sua inteireza por meio de linguagens expressas de formas diferenciadas e sensíveis, tais como as artes visuais, a música, os odores e sabores, as expressões orais e escritas, em combinação e sintonia. A Geopoética propicia o desenvolvimento de projetos criativos e significativos nas mais distintas áreas do conhecimento, pois "toda criação da mente é, fundamentalmente, poética" (WHITE, 1990). No patrimônio natural, a imagem poética já se oferece por si mesma, é imanente. Caberia então, em nossa metodologia, propor as releituras e traduções, que, ao convidarem os sentidos e estimularem compreensões, provoquem uma gênese recíproca entre o ser humano (autor e interlocutor) e a natureza. Cumprir a vocação do poeta é utilizar a linguagem como ferramenta de fazer e pensar ciência, não mais uma ciência que afasta o ser humano da Terra, mas sim uma que reforça, pela Geopoética, o seu vínculo (GALLO, 2015). Assim, a poesia que estrutura o Canto da Mata vai buscar nos parques nacionais e outras UC seus aspectos mais 
|Francisco Fernando Livino de Carvalho | Luiza Corral Martins de Oliveira Ponciano|

expressivos, a fim de traduzi-los, com o objetivo de seduzir e convidar o público, mas também pela necessidade de expor provocações que essas áreas fazem palpitar no espírito do autor. São convites ao encantamento, mas também representam gritos de alerta quanto à importância da conservação desses lugares, ameaçados pelo modelo socioeconômico vigente. Espécies típicas dos ambientes protegidos, características biológicas, culturais e paisagísticas são os elementos que compõem a narrativa poética das canções, que se estruturam em teias musicais afins aos territórios nos quais as áreas se inserem, com as melodias, as harmonias e os ritmos que fazem, da música, uma linguagem de leitura universal. Mesmo para aqueles capazes de, pelo domínio da língua, captar a mensagem das palavras, o envoltório instrumental funciona como um catalizador capaz de ampliar o alcance da mensagem, quase como que dando asas à poesia que, cantada, tende a atingir um público exponencialmente maior, do que apenas lida. A música passa a fazer parte da paisagem sonora, compondo, enquanto expressão artística, o universo simbólico associado a essas áreas, tanto para o autor, como para quem a escuta, oferecendo-se, inclusive, como objeto de estudo geográfico (TORRES; KOZEL, 2010).

Assim como a metodologia utilizada pelos pintores chineses citada acima, as composições do projeto Canto da Mata são resultado de mais de 18 anos de vivências nas UC brasileiras, tanto em atividade profissional quanto em atividades de deleite, nas quais as duas formas de estar acontecem de maneira praticamente indissolúvel. Desse modo, as almas dos lugares vividos se mesclaram e são, hoje, parte integrante da alma geopoeta do compositor, que se traduz em cada uma das obras apresentadas a seguir:

A primeira UC a receber uma "ode" foi o Parque Nacional da Serra da Bocaina, maior parque de Mata Atlântica costeira do país. O projeto se inicia enquanto o primeiro autor era responsável por sua gestão, o que propiciou quase 10 anos de intenso mergulho (em todos os aspectos) na região.

Distribuindo seus pouco mais de cem mil hectares ao longo de quatro municípios paulistas (São José do Barreiro, Areias, Cunha e Ubatuba), além de Paraty (do qual abarca cerca da metade do município) e Angra dos Reis, no estado do Rio de Janeiro, o Parque da Bocaina tem como característica ímpar o fato de proteger áreas contínuas de Mata Atlântica desde o mar até altitudes superiores a dois mil metros, o que faz com que ele proteja praticamente todas as fitofisionomias típicas do bioma, desde os ambientes costeiros, até os campos de altitude. A diversidade paisagística e climática decorrente dos contrafortes da Serra do Mar se materializa em nichos variados, responsáveis por consequente endemismo e diversidade de espécies extremamente alta, incluindo algumas das últimas populações de espécies criticamente ameaçadas, tais como a jacutinga (Alburria jacutinga) e o muriqui 
|Francisco Fernando Livino de Carvalho | Luiza Corral Martins de Oliveira Ponciano|

(Brachyteles arachnoides), maior primata das Américas e uma das espécies mais emblemáticas da Mata Atlântica. Além dos aspectos naturais, a Serra da Bocaina se encontra em uma região de culturas altamente contrastantes e extremamente próximas, entre o sotaque caipira das serras paulistas, onde o aroma é o do leitão à pururuca, do cordeiro assado e do café torrado na hora, e o bronzeado caiçara do litoral fluminense, separados por menos de uma hora, seguindo o caminho da estrada Paraty-Cunha, que corta a UC. A paisagem da região guarda, ainda, alguns dos principais testemunhos do processo de interiorização do país, materializados nos caminhos do ouro e do café, cujas ruínas e arquitetura vernacular ainda resistem nos sertões da Bocaina. Toda essa diversidade, natural e cultural, faz do Parque Nacional da Serra da Bocaina um dos mais visitados do país, embora ainda em estágio de consolidação de suas estruturas gerenciais, necessárias para a formalização e qualificação de seu ecoturismo (IBAMA, 2002; ICMBio, 2010; CARVALHO, 2018).

Como primeira obra, e possivelmente a mais densa, a composição "Morena de Serra, azul de mar”, merece uma análise pormenorizada de seus versos, materializando-se como um estudo de caso, a fim de demonstrar a viabilidade da utilização da música como um instrumento, não só de interpretação ambiental, mas também como de estudo geográfico. Outras composições que também fazem parte do projeto Canto da Mata, serão apresentadas posteriormente, entretanto seguidas de análises mais resumidas, até pela limitação de tamanho imposta pela publicação.

O conteúdo destas análises se presta a estar exposto nos centros de visitantes e ao longo das trilhas das unidades de conservação de forma convencional (como em painéis, folhetos e outros materiais impressos ou virtuais associados com as exposições interpretativas dos parques). As canções, entretanto, seja em si mesmas, seja como enredo de audiovisuais (ou outras linguagens, como o teatro, por exemplo), têm possibilidades mais amplas de veiculação: tanto nos espaços utilizados pelos visitantes, podendo inclusive atraí-los para exposições tradicionais mais detalhadas, quanto por meio das redes sociais e veículos de mídia, como televisão e cinema, que poderiam atingir um grande público, ampliando, potencialmente, o alcance da mensagem da conservação em nossa sociedade, expandindo-se para além dos limites das UC.

\section{MORENA DE SERRA, AZUL DE MAR ${ }^{7}$ :}

(1) "Tem florada na serra, é o manacá": o manacá-da-serra (Tiboucbina mutabilis) é uma árvore de porte baixo a médio, de características pioneiras. Por suas características

${ }^{7} \underline{\text { https://soundcloud.com/user-313220480/morena-de-serra-azul-de-mar }}$ 
|Francisco Fernando Livino de Carvalho | Luiza Corral Martins de Oliveira Ponciano|

ecológicas acaba por colonizar as beiras das estradas que cruzam e margeiam a Bocaina, em suas áreas florestais, principalmente ao longo da rodovia Rio-Santos (BR101) e da estrada Paraty-Cunha (RJ165). Com floração abundante durante o período de primavera e verão (com ligeira variação ao longo da variação altitudinal), colore com múltiplos tons do roxo ao branco os caminhos, configurando um extraordinário e característico espetáculo. (2) "E essas trilhas de ouro levam ao mar": ao mesmo tempo que a relação serra e mar cria o principal atrativo e diferencial da Serra da Bocaina, este contraste é ainda valorizado por ser trespassado por inúmeros caminhos históricos que conduziram à interiorização do país, ligando o ouro das Minas Gerais, e o café do Vale do Paraíba, aos portos do litoral abrigado do sul fluminense. Trilhas como a do Mambucaba, do Guaripu, do Taquari, dentre outras, carregaram a riqueza que construiu (ou saqueou?) o país, e se oferecem hoje ao visitante, ostentando uma riqueza ainda maior e atemporal. (3) "Não há pedra mais bela que a Macela": situada no município de Paraty, mas com acessos e ligação afetivo-turística com Cunha, a Pedra da Macela é um mirante a 1.840 metros de altitude, à beira-mar, e se debruça sobre a vastidão das matas da Bocaina. De beleza ímpar, é um dos maiores atrativos turísticos da região. Dispõe de extremo apelo para a sensibilização do visitante quanto à conservação das paisagens naturais brasileiras. (4) "E as fachadas em forma de aquarela": as cidades que circundam o parque, notadamente São José do Barreiro, Areias e Paraty, têm sua ambiência destacada pelos casarios dos séculos passados. Somando-se aos incontáveis atrativos naturais da região, a sua arquitetura e urbanismo inspiram palavras, amores e inúmeras paisagens afetivas. (5) “Tem história o Brasil passou por lá": o vale histórico do café e os portos de Paraty e Angra contam, ainda hoje, importantes capítulos da história do Brasil, da formação de nossa imagem e de nossos personagens. (6) "Paraty, São José do Barreiro, Areias, Cunha, Ubatuba e tem Angra dos Reis e de Iemanjá”: são seis municípios que têm, com a área protegida, uma relação de simbiose, por motivos diversos: enquanto os municípios serranos de São Paulo - lugares em que "não se conjugam verbos no presente, tudo é pretérito", como profetizara o escritor Monteiro Lobato, em seu livro “Cidades Mortas" (REMÍGIO, 2013) - têm no parque o mais promissor vetor de resgate econômico, os três municípios litorâneos, importantes destinos turísticos do país, precisam da proteção que a unidade de conservação confere aos seus atributos naturais, sob pena do comprometimento de sua atratividade turística e consequente sustentabilidade socioeconômica. (7) "Tem caminhos no alto a te guiar": não há um consenso absoluto acerca do significado do nome Bocaina, mas recorrentemente se faz referência a caminhos no alto da serra: "abertura ou depressão numa serra ou cordilheira; passagem estreita entre 
|Francisco Fernando Livino de Carvalho | Luiza Corral Martins de Oliveira Ponciano|

duas elevações de terreno" Caminhos do Alto" (MATTOSO; BRAGA, 1990). (8) "Mulungu, louro, ipê, jequitibá / tem canela, pinhão, sibipiruna": a riqueza da flora da Bocaina não se registra apenas pela diversidade das espécies, mas pelo porte de suas árvores, guardiãs centenárias dessas matas. Alguns jequitibás (Cariniana sp.) que reinam nos mais recônditos vales da Bocaina precisam de vários homens para que seja possível abraçar seus troncos portentosos! Já os ipês (Tabebuia sp.) e o mulungu (Erythrina verna) marcam com suas vivas cores o calendário da Bocaina, florescendo sempre antes nas vertentes interiores, para depois colorirem o litoral. Infelizmente, as árvores "de lei", como o ipê e o louro (Cordia sp.), por exemplo, ainda sofrem a pressão das extrações irregulares, mesmo em áreas protegidas, consequência da reduzida estrutura de pessoal dos órgãos ambientais, em especial o ICMBio. Além da madeira, a araucária (Araucaria angustifolia) sofre ainda pressão sobre suas sementes. O popular pinhão, que caracteriza toda uma cultura culinária do inverno serrano e do sul do país, é base alimentar importante para a fauna protegida da Bocaina durante sua "safra". A atratividade das araucárias, entretanto, é utilizada como estratégia de caça por criminosos que adentram o parque nesse período. (9) "Indaiá, Barra Grande, tem Graúna / Mambucaba, teu porto a me esperar...”: nesse trecho a canção migra da flora à geografia do lugar, a partir do Indaiá (Attalea sp.), palmeira importante para a alimentação da fauna que por sua abundância dá nome a uma das regiões localizadas no alto da serra, a partir do município de Cunha, na divisa RJ-SP. São inúmeros os "sertões" que se abrigam na serra (Barra Grande, Graúna, Mambucaba), tendo sido o último um importante porto dos tempos imperiais, recebendo inclusive companhias de teatro da Europa (que, na carga dos tropeiros, serpenteavam a serra para se apresentarem aos ricos senhores do café, no Vale do Paraíba). Tempos carregados de poesia, e de árduas travessias, dos quais a Bocaina ainda guarda as memórias e os caminhos (ANTONIO FILHO, 2014). (10) "Muriqui, araponga, tucano, onça-pintada / e as saíras, com lápis de cor / para te (Paraty) pintar": o fascínio da fauna silvestre em seu ambiente natural sempre foi a principal paixão do compositor. A Serra da Bocaina abriga, possivelmente, uma das maiores populações de muriquis-do-sul (Brachyteles arachnoides) do estado do Rio de Janeiro (IBAMA, 2002), bem como registra ainda alguns dos últimos espécimes da onça-pintada (Panthera onca), já virtualmente extinta nessa região do país, em virtude de sua baixíssima população (MAZZOLLI; HAMMER, 2008). Menos raros, mas nem por isso não menos atraentes, os pássaros que colorem as matas e as embalam em trilha sonora têm na ameaçada araponga (Procnias nudicollis) e no tucano (Ramphastos sp.) ruidosos e vistosos representantes. Os tucanos, inclusive,

${ }^{8}$ https://www.dicionarioinformal.com.br/bocaina/ 
|Francisco Fernando Livino de Carvalho | Luiza Corral Martins de Oliveira Ponciano|

representam bem a diversidade do parque, já que aqui se encontram três das cinco espécies que ocorrem no Brasil, dependendo da região: o tucano-de-bico-preto (Ramphastos vitellinus), nas matas mais baixas da vertente atlântica, o tucano-de-bico-verde (Ramphastos dicolorus), nas matas montanas e o tucanuçu, ou toco (Ramphastos toco), comum nas áreas abertas da vertente voltada para o Paraíba, fora as espécies de araçaris (Pteroglossus sp., Selenidera sp. $e$ Bailonius bailoni) (DUNNING, 1987). Por fim, as diversas saíras (Tangaras sp., Cyanerpes sp., Hemithraupis sp. etc.), sem dúvida alguma, são as mais frequentes joias que se oferecem ao visitante, pintando com suas cores múltiplas e vivas, "de lápis de cor”, as paisagens da Bocaina. O "para te", cantado em versos repetidos, ressalta o município de Paraty, principal porto e porta da Bocaina, não só por abrigar a maior parcela de seu território, mas por servir de acesso à maior parte de seus visitantes. (11) "Bracuhy, Santo Isidro e as quedas do Veado": se os visitantes da Bocaina percorrem os caminhos da serra ao litoral, pelas "trilhas de ouro", as abundantes águas que alimentam ao norte o Rio Paraíba do Sul, e ao sul a Baía da Ilha Grande, se jogam por quedas violentas de beleza cênica fascinante. (12) “Tem o Frade, orgulhoso, que aponta e toca o céu": com 1.578 metros de altitude (IBAMA, 2002), o Pico do Frade não é um dos mais altos da Bocaina, mas é o mais destacado marco de relevo da unidade. Destino para poucos aventureiros, do alto se descortina a imensidão da relação serra, mata e mar, que faz da Bocaina um lugar único. Visto de baixo, torna-se absolutamente "metamórfico" em seu formato, variando desde um estreito pico, que remete ao Dedo de Deus, até um largo alto de morro, à medida que se percorrem as sinuosas curvas da estrada Rio-Santos e se vão sucedendo diferentes escalas, planos, direções e ângulos, variáveis que influem na percepção da paisagem. (13) "Lá no alto as geadas de orvalho congelado": em um mesmo dia, é possível se bronzear ao sol nas praias da Trindade, enquanto no alto da serra, os dias amanhecem brancos de gelo, em típicas paisagens sulistas. A Bocaina tem múltiplos encantos que se oferecem para o ecoturismo, cativando o visitante que, ao se apaixonar, pode vir a se tornar um defensor da (sua) natureza. (14) “Em teu cume a paisagem é de tirar chapéu / para te (Paraty) saudar": elevando-se a 2.088 metros acima do nível do mar, o Pico do Tira Chapéu é o ponto culminante da Serra e, embora se localize em seu limite mais interior, permite nos dias límpidos de outono uma surpreendente vista para o mar. Novamente a expressão "para te" se repete em louvação à cidade que, no ano de 2019, alcançou o reconhecimento como patrimônio mundial pela UNESCO ${ }^{9}$, sendo o primeiro sítio misto do país, associando a cultura de Paraty com a relevância ambiental da Serra da Bocaina. É de tirar o chapéu! (15)

\footnotetext{
${ }^{9}$ http://g1.globo.com/sp/vale-do-paraiba-regiao/link-vanguarda/videos/t/edicoes/v/serra-da-bocaina-virapatrimonio-mundial-pela-unesco/7742954/
} 
|Francisco Fernando Livino de Carvalho | Luiza Corral Martins de Oliveira Ponciano|

“Tanta mata que a praia se ergue em ti, Bocaina / Na Trindade o convite da serra é mergulhar / Teu mergulho é cultura, é vida, é parque, é água...”: com números de visitantes que atingem, nos momentos de pico, registros equivalentes aos do Cristo Redentor, a Trindade é um dos maiores desafios gerenciais do parque nacional. Intensos esforços foram feitos pelo ICMBio para resgatar uma praia que se encontrava totalmente tomada por comércios irregulares de bares e estacionamentos. Em fase de consolidação das estruturas ecoturísticas e gerenciais, as praias do Meio e Caixa d'Aço, com suas águas turquesas guardadas por costões e densa mata (Figura 2), com acesso por uma vila de origem caiçara, é um dos principais cartões postais da UC. Segundo Semeia (2012), “o Parque Nacional da Serra da Bocaina, a partir do incremento da sua infraestrutura e oferta turística, pode se posicionar como o melhor destino que congrega natureza e história no país.” (16) “Oh Bocaina, és morena de serra, azul de mar!": como conclusão poética da narrativa o autor rende-se apaixonado aos encantos e às cores da serra e de sua musa, e convida o ouvinte a vivenciar, pessoalmente, a viagem narrada de forma Geopoética.

Postada nas redes sociais, a música "Morena de Serra, azul de mar" já obteve mais de 2,7 mil visualizações apenas no youtube, tendo sido ainda uma das 24 composições classificadas para o I Festival de Música de Paraty, num universo de mais de 500 canções inscritas. Foi ainda apresentada na Conferência Internacional de Interpretação Ambiental, durante o mês de maio de 2019, no Rio de Janeiro, junto às canções "Aquarela" e "caRIOca", que também fazem parte deste artigo. A sua postagem, no escopo do projeto "Minhas canções e suas nascentes", veiculadas pelo Instagram e Facebook, foi a de maior repercussão de toda a série, obtendo mais de 10 mil visualizações ${ }^{10}$, demonstrando o seu apelo geopoético.

Figura 2 - Parque Nacional da Serra da Bocaina.

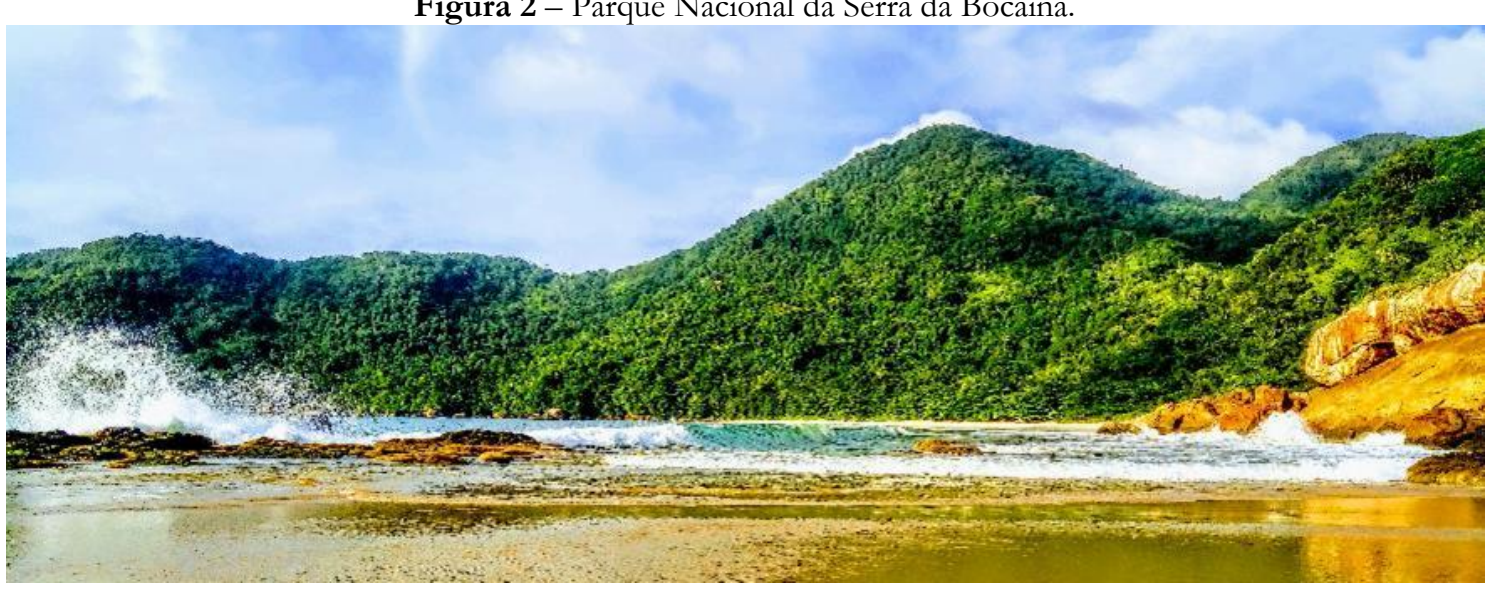

Fonte: Chico Livino.

${ }^{10}$ https://www.facebook.com/1578225595597895/videos/544944689525942 
| Canto da Mata: um convite geopoético aos nossos parques nacionais |

|Francisco Fernando Livino de Carvalho | Luiza Corral Martins de Oliveira Ponciano|

\section{OUTRAS PAISAGENS...}

“Cadê": a próxima música é um misto de louvação e grito de alerta e, em vez de retratar uma unidade de conservação específica, ou um bioma característico, perpassa por diversas unidades de conservação e paisagens brasileiras (Figura 3), assim como visita tempos distintos da vivência do autor, indo desde a formação de sua subjetividade, nas lagoas da região oceânica de Niterói, até a oportunidade de vivenciar uma vasta gama de refúgios selvagens do país, por meio de sua experiência profissional.

CADÊ!?11: Cadê!? No fim da tarde voam/ na beira da lagoa/ as nuvens de irerê/ cadê!? / Cadê!? Nos céus de brigadeiro/ as formações em vê/ dos bandos de colhereiros/ asas rosas em buquê/ cadêl? / Cadê!? As matas de restinga/ praia, Piratininga o voo sangue do tiê/ cadê!? / Não mais se vê.../ Hoje o que voa é a esperança/ daquilo que ainda trago de criança/ aos filhos poder dar como herança/ e a vida que resiste ser capaz de proteger: as matas da Bocaina/ banhados do Taim/ cerrados pantaneiros/ variedades de sauim/ o rio Juruena/ águas do Japurá/ as aves de Noronha/ muriqui, tamanduá.../ Serra da Capivara/ Serra das Confusões/ Raso da Catarina/ variedades de sertões/ veredas e chapadas/ Veadeiros, Diamantina/ a água cristalina que não cessa de correr/ a vida nos ensina/ é tempo de aprender/ que a vida que resiste/ é necessário proteger/ pr'os filhos de outros filhos/ termos como responder:/ Cadê!?

Figura 3 - Parque Nacional do Pantanal Matogrossense.

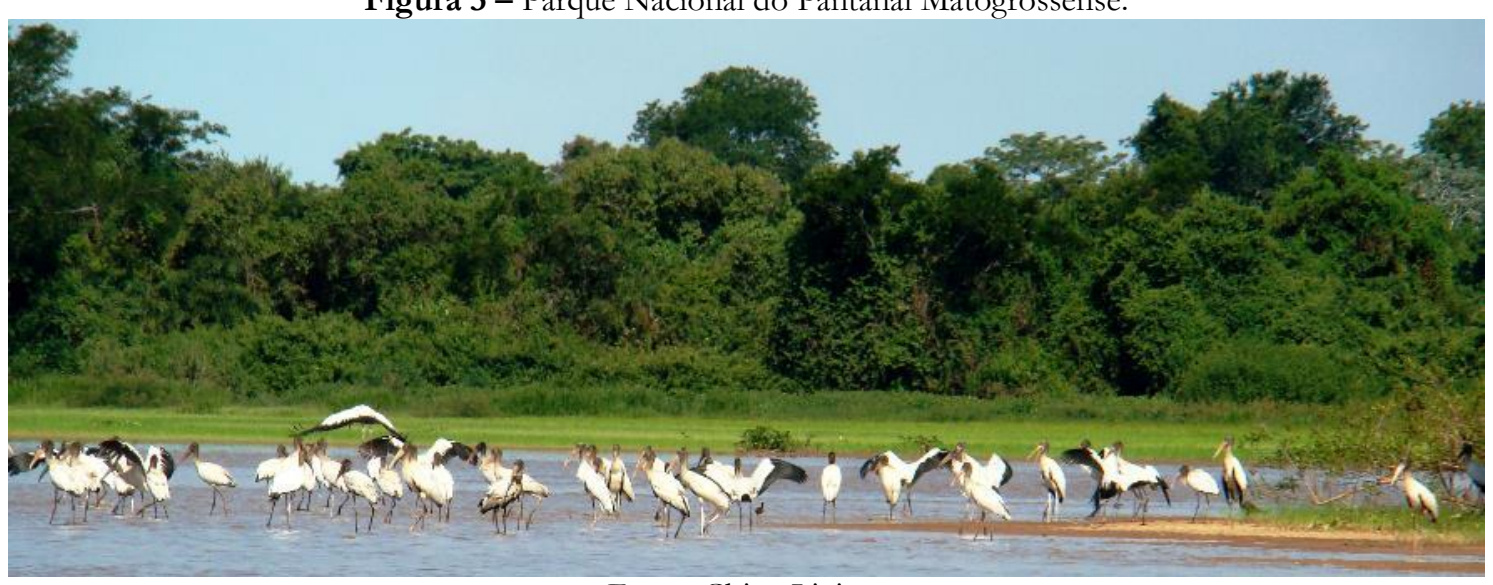

Fonte: Chico Livino.

“Explosão de Vida": composição feita por encomenda para a celebração dos 80 anos do Parque Nacional do Itatiaia (junho de 2017), reúne diversas referências, tanto em paisagens que se encontram na subjetividade do autor, quanto na objetividade do território.

${ }^{11}$ https://www.facebook.com/1578225595597895/videos/676984366367459 
|Francisco Fernando Livino de Carvalho | Luiza Corral Martins de Oliveira Ponciano|

O trecho "Vale do Pavão, Maringá/ quero um 14 bis pra voar" remete ao vale de um dos rios do parque, que rega e cria atrativos na região de Maringá, próximo a Visconde de Mauá (RJ), ao mesmo tempo em que se refere a uma canção da banda $14 \mathrm{Bis}^{12}$. Nas "asas do 14 Bis", portanto, o autor pede carona e convida o ouvinte a se encantar com a vastidão do planalto do Itatiaia, uma das regiões mais altas do país, de onde se pode ver o sol nascer "lá embaixo". A região geográfica da fronteira entre os estados de Minas Gerais e Rio de Janeiro é retratada pelas águas dos rios Aiuruoca e Campo Belo, alguns dos mais significativos da unidade.

EXPLOSÃO DE VIDA13: Pedras preciosas são tesouros em tuas prateleiras/ a águia rasga o manto tricotado por agulhas negras/ as asas são presentes de Chagal pra levar a morena (levar a morena!)/ é a joia da coroa que consagra a vasta Mantiqueira/ águas cristalinas dão refresco ao velho Paraíba/ rica e densa mata virgem presta abrigo a essa explosão de vida/ Vale do Pavão, Maringá/ quero um 14 bis pra voar/ planalto infinito pro olhar/ lá embaixo o sol que raia/ o estranho gargalhar do sauá/ orar aos pés de um jequitibá/ cada imenso tronco é um altar/ sagrado Itatiaia!/ Em ti começa a história protegendo as matas brasileiras/ ciência e aventura, és desejada desde a realeza/ o vale do Aiuruoca a regar as paisagens mineiras/ descendo o Campo Belo me banhar num leito carioca/ o espírito imortal de Jobim/ rege o cantar do papa-capim/ e os tangarás que dançam pra mim/ na arena de batalha/ passadas de uma onça ao luar/ segredos que se deixam mostrar/ àqueles que escolheram pra amar/o Parque Itatiaia.

"caRIOca": é um samba, com uma levada quase de samba enredo, para retratar a mais significativa paisagem e "moldura" do Rio de Janeiro, celebrando o título de paisagem cultural concedido pela UNESCO ${ }^{14}$. Com a maior floresta urbana recuperada do mundo, o Parque Nacional da Tijuca é fruto de uma bem-sucedida e pioneira iniciativa de recuperação florestal dos maciços da cidade pelo Imperador Dom Pedro II, ao notar a crise hídrica que se instalava no Rio de Janeiro, fruto do intenso desmatamento, motivado pela cultura cafeeira (DRUMMOND, 1988). Menor parque nacional do país (MMA, 2019), é, ao mesmo tempo, o mais visitado, com números próximos de três milhões de visitantes por ano. A composição "caRIOca" retrata ambientes e espécies que normalmente não fazem parte do imaginário de uma população urbana como a do Rio de Janeiro, sendo possível vivenciar experiências de completo isolamento e conexão intensa com os estímulos naturais

\footnotetext{
12 https://www.youtube.com/watch?v=1n1zD-Odvd0

13 https://www.facebook.com/100015533806205/videos/271189166742208/

${ }^{14}$ https://www.archdaily.com.br/br/801657/rio-de-janeiro-e-a-primeira-paisagem-cultural-urbana-declaradapatrimonio-mundial-da-unesco
} 
|Francisco Fernando Livino de Carvalho | Luiza Corral Martins de Oliveira Ponciano|

bem no centro de uma das maiores metrópoles da América Latina. Em face do apelo do parque, esta composição foi escolhida para ser um piloto do projeto Canto da Mata em sua expressão integral. Com linguagem pensada para se comunicar com um vasto público, além dos amantes da natureza já convertidos, o audiovisual "caRIOca" foi pensado para ser divulgado em diversos veículos, desde exposições interpretativas a redes sociais e, idealmente, grandes veículos de mídia, tais como televisão e cinema. Entretanto este alcance requer política institucional e parcerias diversas, tais como com empresas, concessionários, terceiro setor, dentre outros. Um singelo e importante exemplo do potencial de linguagem do produto se dá pela reação da sobrinha do autor, de 12 anos, que ao assistir o vídeo pela primeira vez pediu de presente de aniversário à avó, ir conhecer o Parque Nacional da Tijuca.

caRIOca15: De minha cidade és a moldural és meu refresco, és men quintall tua silhueta é escultura, tu és paisagem cultural/ és fauna, és flora, esporte e abrigo/ és de beber, és de banhar/ é em ti que nasce o carioca, és, do Brasil, cartão postal!/ Tijuca mata protetoral és hoje parque nacional/ iniciativa salvadoral sabedoria imperial/ abre os teus braços sobre o rio/ e dá-lhe asas pra voar/ asas com as cores dos tucanos, beija-flores, tangarás/ Tijuca mata protetora/ com tuas copas altaneiras/ aqui nasce o Maracanãl que é ave e é a alma das bandeiras/ que te colorem, nosso Rio/ perpetuando o carnavall a cada jogo de domingo, de dor, de amor, de sol, de sall do alto do Corcovado/ aos pés de um jequitibál entre cedros e paineiras/ é onde canta o sabiál onde o Rio é mais sagrado/ mais saudável, mais lugar/ encantas a quem visital tua floresta oferta o mar/ Tijuca mata protetoral com tua fauna protegidal abrigas pregos e bugios/ quatis, tantas formas de vidal teus sons ecoam pela matal em tuas trilhas de aventuras/ a água desce e acaricia, por entre os vãos a pedra dural Pedra da Gávea/ Dois Irmãos/ és Pretos Forros, Sumaré/ água que jorra do grotão/ bela cascata de Taunay/ casarões, pontes e fontes/guardam a herança do país/ lançando bem alto as copas/ aprofundas minha raiz:

“Aquarela": a última canção que ilustra esse artigo, foca principalmente na fauna que habita as "paisagens sertanejas de confins bem brasileiros". Personagens principais da narrativa, os animais são o principal elo de ligação afetiva não só do autor, mas de muitos que se encantam pela Natureza. Marcantes na paisagem por suas cores e formas, como as araras (Ara sp. e Anodorynchus sp.), elas, assim como outras espécies, têm influência expressiva também na "paisagem sonora" (KOZEL, 2012). Alguns animais, inclusive, dificilmente são vistos, sendo mais comumente identificados por seus sons, como o saci (Tapera naevia), que no início da primavera torna-se quase uníssono na paisagem de campos

${ }^{15} \underline{\text { https: } / / \text { www.youtube.com/watch?v }}=x$ xm5I-jFtg1s 
|Francisco Fernando Livino de Carvalho | Luiza Corral Martins de Oliveira Ponciano|

e bordas de florestas brasileiras. Sentimentos como nostalgia e saudade se associam com expressões da fauna, criando vínculos afetivos que são propalados com ênfase no refrão que utiliza literalmente uma "espécie bandeira" (KUNIEDA, 2003), o tamanduá (Myrmecophaga tridactyla), para criar uma apoteose estética na narrativa, tanto poética quanto musical e visual (Figura 4).

AQUARELA16: "Pergunto qual arara você acha mais bonita/ eu digo que bonito é a gente ver elas voando/ piranga, canindé, vermelha, azul, bonito é quando/ o grito rasga forte a paisagem que se fita/ paisagem sertaneja, de confins bem brasileiros/ só olhar não cabe inteiro, tem que abrir o coração/ deixar-se se encantar com os sons e cores da floresta/ ser parte dessa festa que orgulha o nosso chão/ tamanduá ergue a bandeira que a passarada coloriu/ eu quero expor nessa aquarela, cores e formas do Brasil!/ A arara é a grande musa, mas tem tanta coisa bela/ e aqui nem tem janelas, dá pra ver a imensidão!/ veredas no sertão, berço de vida do cerrado/ e eu fico admirado só de olhar o voo delas!/ Pergunto então se ouviu o gargalhar da seriema/ ou se já sentiu pena do lamento do saci/ que entoa sua cantiga anunciando a primavera/ e cantando assim espera ter a fêmea para si.../ Que é como eu faço agora entalhando esse poema/ estou longe da morena e a saudade dói demais/ mas serve de tempero pra, depois, vontade imensa!/ tal qual disse o Valença: no amor dois animais.../ e então por fim convido a conhecer esses recantos/ sorver tantos encantos, se deixar admirar/ por voos coloridos, por olhares de rapina/ em sintonia fina com o melhor do meu lugar.

Figura 4: Estudos em aquarelas para painéis de azulejos.
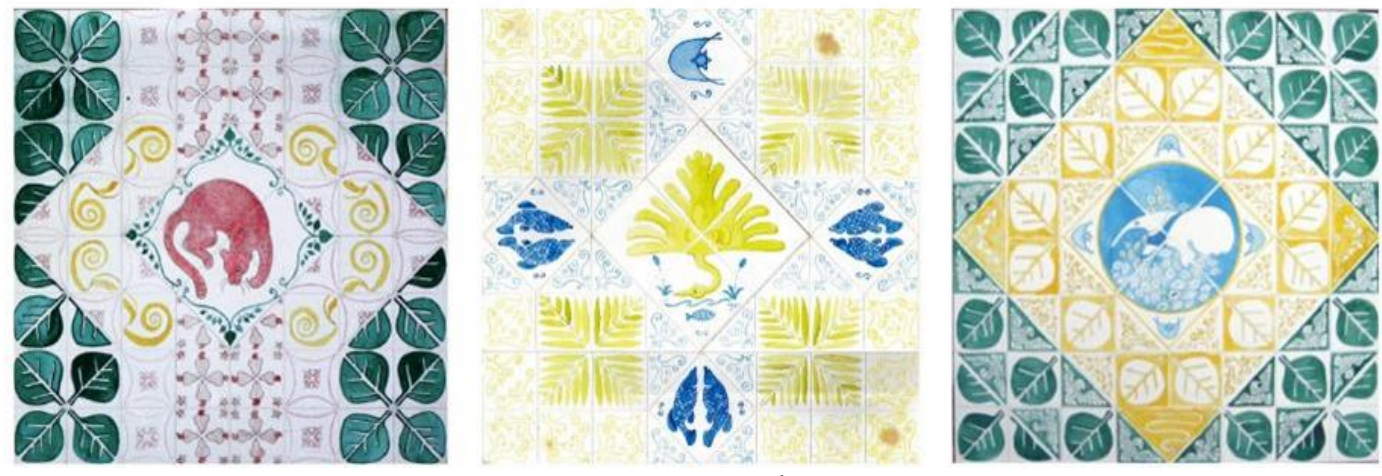

Fonte: autoral.

\section{CONSIDERAÇÕES FINAIS}

Canto da Mata busca retratar a Natureza como faziam os grandes viajantes

${ }^{16}$ https://www.youtube.com/watch?v=lHulpZ6DGaA 
|Francisco Fernando Livino de Carvalho | Luiza Corral Martins de Oliveira Ponciano|

naturalistas do século XIX, tais como Humboldt, Langsdorff, Spix ou Martius, aliando investigação e deslumbramento, poesia e paisagem, arte e ciência, sem dualismos. O desenvolvimento deste projeto perante o atual cenário da indústria cultural, que tende a valorizar produções comerciais vinculadas aos estilos da moda, é um árduo desafio. Acreditamos, entretanto, que a sua inserção via cenário especializado das unidades de conservação tende a oferecer outros caminhos de divulgação. Em contrapartida, uma possível crescente aceitação pública tende a valorizar e promover as unidades de conservação. O incremento de mídias, por meio da associação da linguagem da música e da poesia com imagens (fotos e vídeos) tende a alcançar um efeito catalizador na promoção artística, aumentando a atratividade e diversificando os canais de divulgação, cada vez mais multimídia, o cenário contemporâneo da música popular assim indica.

Concluímos que é necessário continuar buscando novas formas de comunicar a importância da conservação dos parques nacionais e outras UC brasileiras para um público cada vez maior, e não apenas com matérias jornalísticas, científicas e turísticas, mas também com um apelo poético, estético, afetivo e subjetivo, que pode despertar outras parcelas da nossa sociedade por meio do estímulo das emoções e dos sentidos. A geopoética como caminho, a interpretação ambiental como veículo.

\section{REFERÊNCIAS}

ANTONIO FILHO, Fadel David. Opulência e decadência da cultura cafeeira e do tropeirismo no vale histórico da Serra da Bocaina (SP). OLAM - Ciência \& Tecnologia, Rio Claro, v. 1, n. 1, p. 5-32, jan./jun. 2014. Disponível em: $<$ https://www.periodicos.rc.biblioteca.unesp.br/index.php/olam/article/view/8786>. Acesso em: 13 ago. 2019.

BRAGA, Alice Serpa; MACIEL, Marcela Albuquerque. O sistema nacional de unidades de conservação e o desafio de sua implementação. In: THEODORO, Suzi Huff. Os 30 anos da Política Nacional de Meio Ambiente: conquistas e perspectivas. Rio de Janeiro: Garamond, 2011. p. 139-162.

CALVO-MUÑOZ, Clemente. Niños y Naturaleza, de la teoría a la práctica. Medicina Naturista, Zaragoza, v. 8, n. 2, p. 73-78. 2014. Disponível em: $<$ https://dialnet.unirioja.es/descarga/articulo/4847929.pdf>. Acesso em: 23 mar. 2019.

CANTERO, Nicolas Ortega. El lugar del paisaje en la geografia moderna. Estudios Geográficos, Madrid, v. LXXI, n. 269, p. 367-393, jul./dez. 2010. Disponível em: $<$ https://www.researchgate.net/publication/270078576 El lugar del paisaje en la geog rafia moderna>. Acesso em: 06 jan. 2021.

CARVALHO, Isabel Cristina de Moura. Educação ambiental: a formação do sujeito ecológico. São Paulo: Cortez editora, 2016. 
|Francisco Fernando Livino de Carvalho | Luiza Corral Martins de Oliveira Ponciano|

CARVALHO, Francisco Fernando Livino de. A atuação do ICMBio em Paraty:: Parque Nacional da Serra da Bocaina. In: TARDIN, Raquel. Análise, ordenação e projeto da Paisagem: uma abordagem sistêmica. Rio de Janeiro: Rio Books, 2018. p. 411-429.

CRAPEZ, Pierre. Imagens da cidade e Geopoética. 2015. 316 f. Tese (Doutorado em Arquitetura e Urbanismo) - Universidade Federal Fluminense, Niterói, Rio de Janeiro, 2015.

CRAPEZ, Pierre. Por uma geopoética urbana (Arte, Cidade, Paisagem). Geograficidade, Niterói, v. 7, n. 2, p. 49-60, inverno 2017. Disponível em: $<$ https://periodicos.uff.br/geograficidade/article/view/12980/pdf $>$. Acesso em: 13 ago. 2019.

DANIEL, Taunay Magalhães. A Epistemologia, o Documentário e o Papagaio: elementos para análise de documentários da vida selvagem. 2009. 297 f. Tese (Doutorado em Multimeios) - Universidade Estadual de Campinas, Campinas, 2009.

DRUMMOND, José Augusto. O jardim dentro da máquina: breve história ambiental da Floresta da Tijuca. Revista Estudos Históricos, Rio de Janeiro, v. 1, n. 2, p. 276-298, dez. $1988 . \quad$ Disponível em:

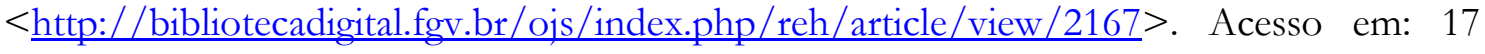
jun. 2019.

DUNNING, John S. South American Birds - A photographic aid to identification. Pennsylvania: Harrowood, 1987.

FORTES Junior, Hugo Fernando Salinas. Transversalidades entre Arte e Ciência nas imagens da Natureza contemporânea. In: ANPAP, 18., 2009, Salvador. Anais... Salvador, 2009.

FREY, Klaus. Políticas públicas: um debate conceitual e reflexões referentes à prática da análise de políticas públicas no brasil. Planejamento e Políticas Públicas, Brasília, n. 21, p. 211-259, jun. 2000. Disponível em: $<$ https://ipea.gov.br/ppp/index.php/PPP/article/view/89>. Acesso em: 21 jun. 2019.

GALLO, Priscila Marchiori Dal. Explorações geopoéticas: amplidão e nostalgia no romance Out of Africa como o dizer poético da geografia. Geograficidade, Niterói, v. 5, n. especial, p. 89-103, Primavera 2015. Disponível em: < https://periodicos.uff.br/geograficidade/article/view/12931/pdf $>$. Acesso em: 13 mar. 2020 .

GUIMARÃES, Solange Terezinha de Lima. Reflexões a respeito da paisagem vivida, topofilia e topofobia à luz dos estudos sobre experiência, percepção e interpretação ambiental. Geosul, Florianópolis, v. 17, n. 33, p. 117-141, 2002. Disponível em: $<$ https://periodicos.ufsc.br/index.php/geosul/article/view/13971>. Acesso em: 19 fev. 2019.

HANAI, Frederico Yuri; NETTO, Joviniano Pereira da Silva. Instalações ecoturísticas em espaços naturais de visitação: meios para propiciar a percepção e a interpretação ambientais. OLAM Ciência \& Tecnologia, Rio Claro, v. 6, n. 2, p. 200-223, dez. 2006. Disponível em: <https://docplayer.com.br/70197861-Instalacoes-ecoturisticas-em- 
|Francisco Fernando Livino de Carvalho | Luiza Corral Martins de Oliveira Ponciano|

espacos-naturais-de-visitacao-meios-para-propiciar-a-percepcao-e-a-interpretacaoambientais.html>. Acesso em: 14 fev. 2019.

IFLA AMÉRICA. Carta del Paisaje de las Américas. In: Conferência Regional IFLA AR / UAM-A. Ciudad de México, 2018. Disponível em: $<$ https://www.ufpe.br/documents/39726/0/08.Carta+de+las+Americas final 12.pdf/1c 7926b7-4667-4bee-ae7b-fce008af9f9b > . Acesso em: 06 jan. 2021.

INSTITUTO BRASILEIRO DE GEOGRAFIA E ESTATÍSTICA - IBGE. População rural e urbana. [S. 1.], 2019. Disponível em: <https://educa.ibge.gov.br/jovens/conhecao-brasil/populacao/18313-populacao-rural-e-urbana.html>. Acesso em: 23 abr. 2019.

ICCA - INSTITUTO CULTURAL CRAVO ALBIN. Dicionário Cravo Albin da Música Popular Brasileira. Rio de Janeiro, 2019. Disponível em:

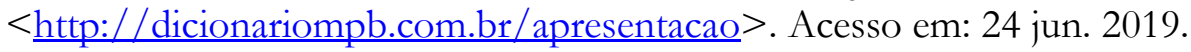

INSTITUTO SEMEIA. Relatório de Premissas e Mix de Produtos e Serviços Passíveis de Concessão em Unidades de Conservação. Instituto SEMEIA/ABETA. São Paulo: SEMEIA, 2012.

KOZEL, Salete. Geopoética das paisagens: olhar, sentir e ouvir a "natureza". Caderno de Geografia, Belo Horizonte, v. 22, n. 37, p. 65-78, 2012. Disponível em: $<$ http://periodicos.pucminas.br/index.php/geografia/article/view/3418>. Acesso em: 12 maio 2019.

KUNIEDA, Edna. Percepção ambiental e aplicação da estratégia da espéciebandeira para a conservação de um fragmento de floresta estacional semidecídua (Fazenda Canchim-CPPSE-EMBRAPA, S. Carlos, SP). 2003. Dissertação (Mestrado em Ciências da Engenharia Ambiental) - Universidade de São Paulo, São Carlos, 2003.

LOUV, Richard. "Déficit de Natureza" provoca problemas físicos e mentais em crianças, alerta especialista. BBC News Brasil, São Paulo, p. 1-13, 25 jun. 2016. Disponível em:

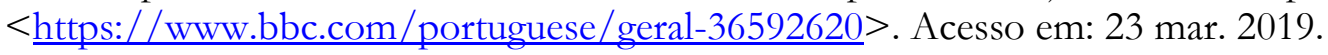

MATTOSO, Adriana; BRAGA, Nina Almeida. Bocaina, Caminhos do Alto. Rio de Janeiro: Independente, 1990. VHS.

MAZZOLLI, Marcelo; HAMMER, Matthias Ludwig Alfons. Qualidade de ambiente para a onça-pintada, puma e jaguatirica na Baía de Guaratuba, Estado do Paraná, utilizando os aplicativos Capture e Presence. Biotemas, Florianópolis, v. 21, n. 2, p. 105-117, jan. 2008. Disponível em: https://periodicos.ufsc.br/index.php/biotemas/article/view/21757925.2008v21n2p105. Acesso em: 13 mai 2019.

MENDONÇA, Rita; NEIMAN, Zysman. Ecoturismo: discurso, desejo e realidade. Turismo em Análise, São Paulo, v. 11, n. 2, p. 98-110, nov. 2000. Disponível em: <http://www.revistas.usp.br/rta/article/view/63521>. Acesso em: 25 fev. 2019.

MENÉNDEZ, Inés Gómez. Experimentar-se Natureza: uma proposta de práticas para o encontro. 2018. 141 f. Dissertação (Mestrado em Ecoturismo e Conservação) Universidade Federal do Estado do Rio de Janeiro, Rio de Janeiro, 2018. 
|Francisco Fernando Livino de Carvalho | Luiza Corral Martins de Oliveira Ponciano|

MINISTERIO DA AGRICULTURA (Chile). CONAF. Estadísticas de Visitación: Parques Nacionales. [S. 1.], 6 jan. 2021. Disponível em: < https://www.conaf.cl/parquesnacionales/visitanos/estadisticas-de-visitacion/>. Acesso em: 6 jan. 2021.

MINISTÉRIO DO MEIO AMBIENTE. Cadastro Nacional de Unidades de Conservação. [S. 1.], 29 maio 2019. Disponível em: <http://www.mma.gov.br/areasprotegidas/cadastro-nacional-de-ucs >. Acesso em: 29 maio 2019.

MINISTÉRIO DO MEIO AMBIENTE (Brasil). IBAMA. Plano de Manejo do Parque Nacional da Serra da Bocaina. Brasília: IBAMA, 2002. Disponível em: $<$ http://www.icmbio.gov.br/parnaserradabocaina/extras/62-plano-de-manejo-emonitorias.html>. Acesso em: 3 jul. 2019.

MINISTÉRIO DO MEIO AMBIENTE (Brasil). ICMBio. Interpretação Ambiental nas Unidades de Conservação Federais. Brasília: [s. n.], 2018. Disponível em: < http://www.icmbio.gov.br/portal/images/stories/comunicacao/publicacoes/publicacoe s-diversas/interpretacao ambiental nas unidades de conservacao federais.pdf $>$. Acesso em: 11 fev. 2019.

MINISTÉRIO DO MEIO AMBIENTE (Brasil). ICMBio. Monitoramento da visitação em Unidades de Conservação Federais: Resultados de 2019 e breve panorama histórico. Brasília-DF: [s. n.], maio 2020. 38 p. Disponível em: $<$ https://www.icmbio.gov.br/portal/images/stories/comunicacao/publicacoes/monitora mento visitacao em ucs federais resultados 2019 breve panorama historico.pdf $>$.

Acesso em: 6 jan. 2021.

MINISTÉRIO DO MEIO AMBIENTE (Brasil). ICMBio. Parque Nacional da Serra da Bocaina Relatório de Monitoria - Etapa I Área Estratégica Interna Caminhos do Ouro. Brasília: [s. n.], 2010. Disponível em: <http://www.icmbio.gov.br/parnaserradabocaina/extras/62-plano-de-manejo-emonitorias.html>. Acesso em: 11 fev. 2019.

MITTERMEIER, Russell A. [et al.]. Uma breve história da conservação da biodiversidade no Brasil. MEGADIVERSIDADE, Belo Horizonte, v. 1, n. 1, p. 14-21, jul. 2005. Disponível em:

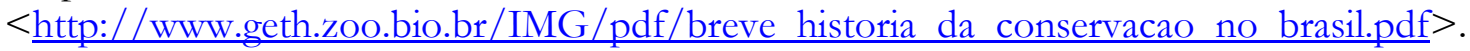
Acesso em: 26 maio 2018.

NPS - NATIONAL PARK SERVICE. Statistical Abstract 2018. Colorado, U.S.: Department of the Interior, 2019. Disponível em: < https://irma.nps.gov/DataStore/DownloadFile/620857>. Acesso em: 25 jun. 2019.

NORBERG-SCHULZ, Christian. O fenômeno do lugar. In: NESBITT, Kate (Org.). Uma nova agenda para a arquitetura. Antologia Teórica 1965-1995. São Paulo: Cosac Naify, 2006. p. 443-461.

OLIVEIRA, Helder Canal de. Um sertão Elomariano: identidade e modernidade na obra de Elomar Figueira Mello. Estudos de literatura brasileira contemporânea, Brasília, n. 54, p. 361-392, maio/ago. 2018. Disponível em: $<$ https://www.scielo.br/scielo.php?pid=S2316-

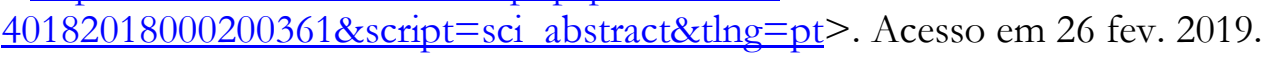


|Francisco Fernando Livino de Carvalho | Luiza Corral Martins de Oliveira Ponciano|

PONCIANO, Luiza Corral Martins de Oliveira. Geotales: narrando as histórias petrificadas pela Terra. Revista Sentidos da Cultura, Belém, v. 5, n. 8, p. 34-48, 2018. Disponível em: $<$ https://periodicos.uepa.br/index.php/sentidos/article/view/2010>. Acesso em: 13 dez. 2018.

REMÍGIO, Marcelo. Vale do Paraíba sofre com esvaziamento populacional. O Globo, Rio de Janeiro, p. s/p., 23 mar. 2013. Disponível em: < https://oglobo.globo.com/brasil/valedo-paraiba-sofre-com-esvaziamento-populacional-7931298 >. Acesso em: 3 jul. 2019.

SALDANHA, Leonardo Vilaça. Música \& Mídia - A música popular brasileira na indústria cultural. In: ENCONTRO NACIONAL DE HISTÓRIA DA MÍDIA, 9., 2013, Ouro Preto. GT de História da Publicidade e da Comunicação Institucional. Ouro Preto: 2013.

SILVA JUNIOR, Orleno Marques da; SANTOS, Marco Aurélio dos; SZLAFSZTEIN, Claudio Fabian. Expansão da geração hidrelétrica e a intervenção em áreas protegidas na Amazônia. In: CONGRESSO BRASILEIRO DE ENERGIA, 16., 2015, Rio de Janeiro. Anais eletrônicos... Rio de Janeiro: COPPE-UFRJ, 2015. Disponível em: $<$ https://www.academia.edu/18156417/Expansao da geracao hidreletrica e a intervenc ao em areas protegidas na Amazonia>. Acesso em: 23 jan. 2019.

TORRES, Marcos Alberto; KOZEL, Salete. Paisagens sonoras: possíveis caminhos aos estudos culturais em geografia. RA'E GA, Curitiba, v. 20, n. 20, p. 123-132, 2010.

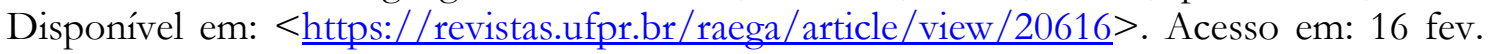
2019.

TUAN, Y. F. Espaço e Lugar: a perspectiva da experiência. Londrina: Eduel, 2013.

TUAN, Y. F. Topofilia: um estudo da percepção, atitudes e valores do meio ambiente. Londrina: Eduel, 2012.

WHITE, Kenneth. Lecture de Laperouse. Cahiers de Géopoétique, n. 1, autonne 1990. Disponível em < http://www.geopoetique.net/archipel fr/institut/cahiers/editorial.html>. Acesso em: 05 set. 2019.

WHITE, Kenneth. No ateliê geopoético. [S. 1.], 1994. Disponível em: $<$ https://www.institut-geopoetique.org/pt/textos-fundadores/105-no-atelie-geopoetico $>$. Acesso em: 15 mar. 2019.

W.E.F. - WORLD ECONOMIC FORUM. The Travel \& Tourism Competitiveness Report 2017. Geneva: World Economic Forum, 2017.

ZIMMERMANN, Andrea. Visitação nos Parques Nacionais Brasileiros: um estudo à luz das experiências do Equador e da Argentina. 2006. 140 f. Dissertação (Mestrado em Desenvolvimento Sustentável) - Universidade de Brasília, Brasília, 2006.

Como citar:

ABNT 
|Francisco Fernando Livino de Carvalho | Luiza Corral Martins de Oliveira Ponciano |

CARVAlHO, F. F. L.; PONCIANO, L. C. M. O. Canto da Mata: um convite geopoético aos nossos parques nacionais. InterEspaço: Revista de Geografia e Interdisciplinaridade, v. 7, e202118, 2021. Disponível em: <http://dx.doi.org/10.18764/2446-6549.e202118>. Acesso em: 19 ago. 2021.

\section{APA}

Carvalho, F. F. L., \& Ponciano, L. C. M. O. Canto da Mata: um convite geopoético aos nossos parques nacionais. InterEspaço: Revista de Geografia e Interdisciplinaridade, v. 7, e202118. Recuperado em 19 agosto, 2021, de http://dx.doi.org/10.18764/2446-6549.e202118

\section{@creative}

This is an open access article under the CC BY Creative Commons 4.0 license.

Copyright (C) 2021, Universidade Federal do Maranhão.

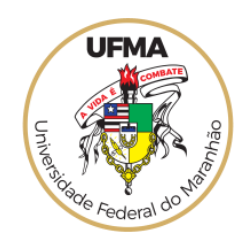

